\title{
Tumor Necrosis Factor Ligand Superfamily Member 12
}

National Cancer Institute

\section{Source}

National Cancer Institute. Tumor Necrosis Factor Ligand Superfamily Member 12. NCI

Thesaurus. Code C117068.

Tumor necrosis factor lig and superfamily member 12 (249 aa, $\sim 27 \mathrm{kDa}$ ) is encoded by the human TNFSF12 gene. This protein plays a role in the positive regulation of angiogenesis. 